\title{
Assessing Enterprise's Knowledge Management Maturity Level
}

\author{
Michel Grundstein \\ MG Conseil, 4 rue Anquetil, 94130 Nogent sur Marne, France \\ Paris Dauphine University, Lamsade CNRS, UMR7024, France F-75016 Paris \\ mgrundsteinamgconseil.fr
}

\begin{abstract}
Knowledge is not manageable as if it was a data or information. Consequently, Knowledge Management (KM) must address activities that utilize and create knowledge more than knowledge by itself. With regard to this issue, we elaborated a sociotechnical approach of Knowledge Management within the enterprise, and we synthesized it into an empirical model called Model for General Knowledge Management within the Enterprise (MGKME). One purpose of this model is to serve as a template to enable assessing the Enterprise's KM maturity level.
\end{abstract}

Keywords: Knowledge Management, Knowledge Management System, Model for General Knowledge Management within the Enterprise (MGKME), Sociotechnical Approach of Knowledge Management, Enterprise's KM Maturity Model, People focused Knowledge Management.

\section{Introduction}

In the Knowledge Society, Enterprises are more and more concerned with Knowledge Management (KM) as a key factor for improving their efficiency and competitiveness. They need a framework that serves as a template to position their efforts and launch KM initiatives. Thus, numerous Knowledge Management (KM) frameworks have been suggested all over the world as mentioned in the European Guide to Good Practices in Knowledge Management edited by the European Committee for Standardization [1]. According to our contribution to this project, we could distinguish two main approaches underlying KM: (i) a technological approach that answers a demand of solutions based on the technologies of information and communication (ICT); (ii) a managerial approach that integrates knowledge as resources contributing to the implementation of the strategic vision of the company. Moreover, we could observe that few of them were "people-focused" as highlighted by Wiig [2]. With regard to these issues, we elaborated a KM Empirical Model so-called Model for General Knowledge Management within the Enterprise (MGKME).

In this article, after having set out the background theories and assumptions, we distinguish the concept of KM Empirical Model from the concept of Knowledge Management System. Then, we make a brief description of MGKME. Finally, we outline an Enterprise's Knowledge Management Maturity Model (EKMMM), transposed from the IT Governance Maturity Model suggested in COBIT $^{\circledR}$ [3], and that rests on the MGKME.

M.D. Lytras et al. (Eds.): WSKS 2008, CCIS 19, pp. 380-387, 2008.

(C) Springer-Verlag Berlin Heidelberg 2008 


\section{Background Theories and Assumptions}

\subsection{The Definition of KM}

In our research group, we consider that knowledge is not an object processed independently of the person who has to act. Thus, it appears that KM addresses activities, which utilize and create knowledge more than knowledge by itself. With regard to this question, since 2001, our group of research has adopted the following definition of KM:

$\mathrm{KM}$ is the management of the activities and the processes that enhance the utilization and the creation of knowledge within an organization, according to two strongly interlinked goals, and their underlying economic and strategic dimensions, organizational dimensions, socio-cultural dimensions, and technological dimensions: (i) a patrimony goal, and (ii) a sustainable innovation goal.

The patrimony goal has to do with the preservation of knowledge, their reuse and their actualization. It is a static goal. The sustainable innovation goal is more dynamic. It is concerned with organizational learning: creation and integration of knowledge at the organizational level.

\subsection{The Enterprise's Sociotechnical Environment}

E. Coakes [4] defines sociotechnical approach as "the study of the relationships and interrelationships between the social and technical parts of any system" (p. 5). From KM viewpoint, the Sociotechnical Environment constitutes the social fabric where autonomous individuals, supported by Information and Communication Technologies (ICT) and tangible resources, interact and are conversing through physical or virtual places (coffee machines, collaborative workspaces, weblogs, wikis, CoPs).

The sociotechnical approach leads to emphasizing the link between knowing and action, with due regard to the basic constraints of the social system that is to give a sense to working time. Thus, KM initiative should result in Knowledge Management System (KMS) components that take into account the individuals, both as components and users of a system that allows them to be autonomous and to achieve their potentialities.

\subsection{The Value Adding Processes}

Value adding processes derive from the value chain described by Porter [5] who identifies nine value-adding activities that he classifies into two main categories. The "primary activities" are: 1) in-bound logistics, 2) operations, 3) out-bound logistics, 4) marketing \& sales, and 5) Services. The "support activities" are: 1) business infrastructure, 2) human resource management, 3) technological development, and 4) supplies. In this way, Value-adding processes represent the organizational context for which knowledge is essential factors of performance. It is in this context that is implanted a KM initiative.

\subsection{The Managerial Guiding Principles}

The Managerial Guiding Principles should bring a vision aligned with the enterprise's strategic orientations, and should suggest a KM Governance principles by analogy 
with COBIT $^{\circledR}$ [3]. In particular, we established KM indicators. Numerous publications and books relates to that subject. From our viewpoint, we constructed two main categories of indicators in order to monitor a KM initiative: (i) a category of indicators that focus on the impacts of the initiative that favor enhancement of intellectual capital, (ii) a category of indicators that insure monitoring and coordination of KM activities, measuring the results, and insuring the relevance of the initiative.

In addition (Ref. Fig. 1), we suggest a way to get a good articulation between the Deming's cycle PDCA [6] and Argyris \& Schön's Organizational learning [7].

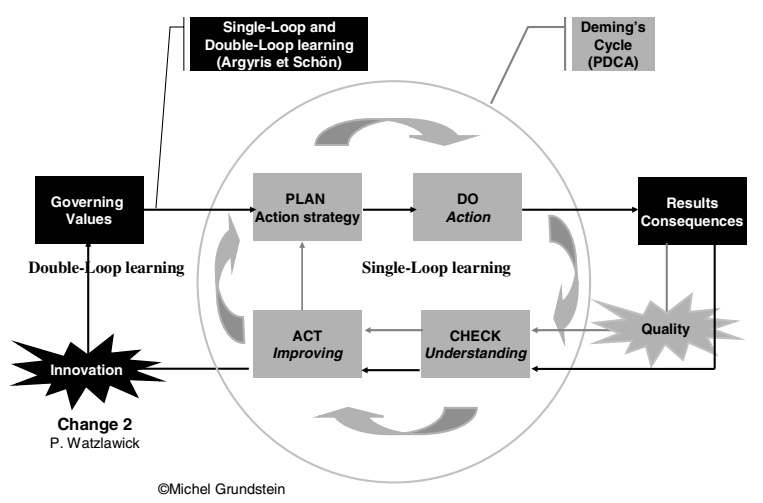

Fig. 1. Deming's cycle and Argyris \& Schön's Organizational learning [8]

Firstly, we refer to the PDCA cycle of activities - plan, do, check, and act [6]; this cycle well known as the Deming's Cycle by Quality Management practitioners, has inspired the ISO 9004 (2000) Quality Standards in order to get a continuous process improvement of the Quality Management System. Secondly, we refer to the SingleLoop Learning and Double-Loop Learning defined in the Argyris \& Schön's organizational learning theory [7].

Furthermore, we should think about the relevant infrastructures, which are adapted sets of devices and means for action. Beyond a network that favors cooperative work, it is important to implement the conditions that will allow sharing and creating knowledge. An ad hoc infrastructure must be set up according to the specific situation of each company, and the context of the envisaged KM initiative. The SECI spiral of conversion Model proposed by Nonaka and Takeuchi [9] and the Japanese concept of $B a$ inspire this infrastructure [10] [11].

\section{KM Empirical Model Versus KM System}

$\mathrm{KM}$ becomes a reality in the implementation of a system. The purpose of this system is to amplify the utilization and the creation of knowledge to improve the enterprise's effectiveness. This system is often called Knowledge Management System (KMS). Therefore, we have to distinguish between the notion of KM Empirical Model that is a template, and the notion of KM System - a context dependant system, which is the implementation of this template in the real world (Ref. Fig. 2). 


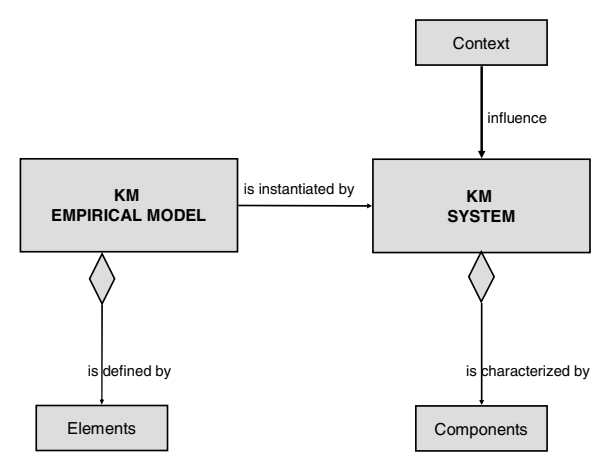

Fig. 2. KM Empirical Model and KM System [12]

To implement KMS components, Enterprises need a general model that is a pattern of reference (a template) in order to integrate KM Governance principles in their strategic vision, and to use KM as a factor that enable improving their efficiency and competitiveness. In this article, we refer to MGKME, our Model of General Knowledge Management within the Enterprise [8] that articulates the enterprise's sociotechnical environment, the enterprise's value-adding processes, and the managerial guiding principles specific to KM.

\section{MGKME, a Model for General Knowledge Management within the Enterprise}

The MGKME, described hereafter (Ref. Fig. 3), supports our full meaning of KM as defined in paragraph 2.1. It is an empirical model based both on our experience within the industry, and on our research works. MGKME rests on a Sociotechnical approach. It focuses on people and value adding processes. Moreover, the MGKME presents an attempt to articulate the Deming's Cycle PDCA and the Single-Loop Learning and Double-Loop Learning defined in the Argyris \& Schön's organizational learning theory. It suggests "ad hoc infrastructures" derived from the Nonaka and Takeuchi's SECI model and the Japanese concept of " $B A$ ". It highlights four generic KM processes [8].

MGKME is composed of two main categories of elements: (I) the underlying elements consist of sociotechnical environment and value adding processes; (II) the operating elements focus on the underlying elements. They consist of managerial guiding principles, ad hoc infrastructures, generic KM processes, organizational learning processes, and methods and supporting tools. Key Issues to address for every elements of each level are synthesized in Table 1 and Table 2. 


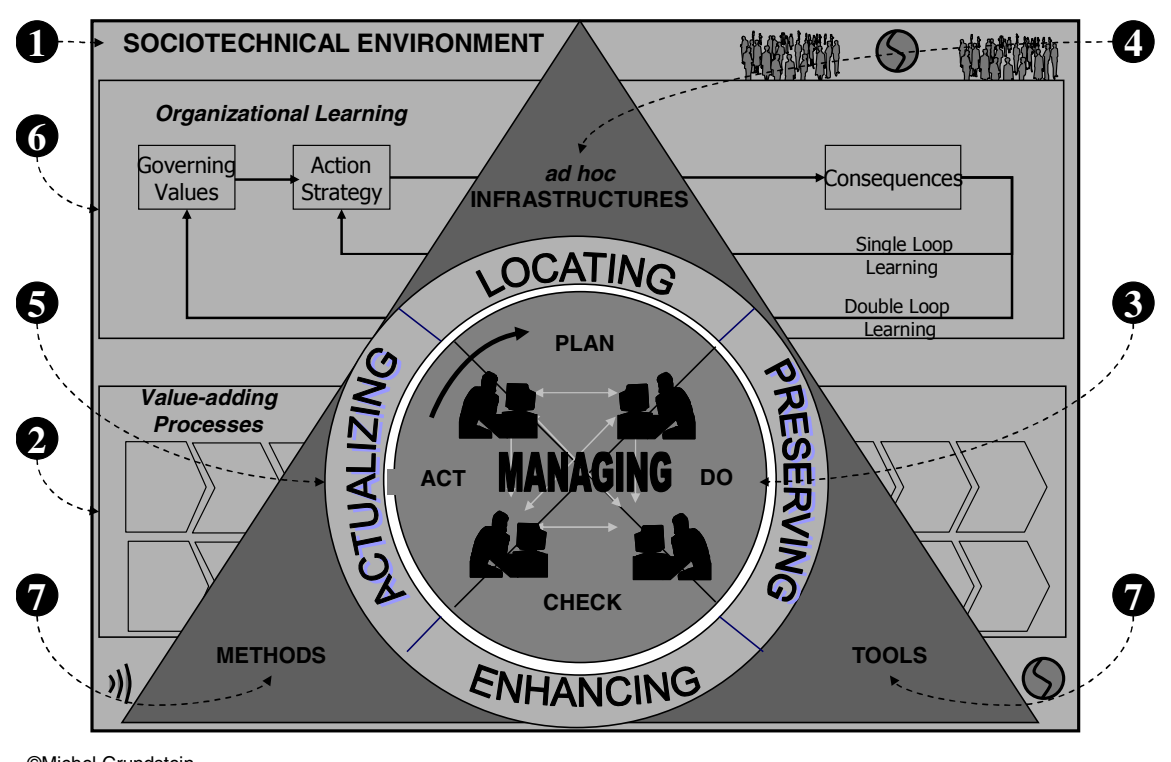

Fig. 3. Model for Global Knowledge Management within the Enterprise [8]

Table 1. MGKME's Underlying Elements

\begin{tabular}{|c|c|c|}
\hline $\begin{array}{l}\text { Model } \\
\text { Level }\end{array}$ & Elements & Key Issues \\
\hline $\begin{array}{l}\text { I } \\
\mathrm{U} \\
\mathrm{N} \\
\mathrm{D} \\
\mathrm{E}\end{array}$ & $\begin{array}{l}\mathbf{1} \\
\text { Sociotechnical } \\
\text { Environment }\end{array}$ & $\begin{array}{l}\text { Enterprise 's Activities (sector, key value-chain elements, geographi- } \\
\text { cal distribution, size, market, mass or batch manufacturing processes, } \\
\text { product lifecycle, oral or written culture) } \\
\text { Relations and Interactions between ICT, Structure, and People: their } \\
\text { roles, their tasks } \\
\text { Capability to learn and Innovate } \\
\text { Social and Intellectual Capital Management Involvement }\end{array}$ \\
\hline $\begin{array}{c}\text { L } \\
\text { Y } \\
\text { I } \\
\mathrm{N} \\
\mathrm{G} \\
\text { LEVEL }\end{array}$ & $\begin{array}{l}2 \\
\text { Value-adding } \\
\text { Processes }\end{array}$ & $\begin{array}{l}\text { Porter's Primary and Support Activities: } \\
\text { Running Processes } \\
\text { Business Processes } \\
\text { Design and Development Processes } \\
\text { Innovative Product and Services Processes }\end{array}$ \\
\hline
\end{tabular}


Table 2. MGKME's Operating Elements

\begin{tabular}{|c|c|c|}
\hline $\begin{array}{l}\text { Model } \\
\text { Level }\end{array}$ & Elements & Key Issues \\
\hline & $\begin{array}{l}3 \\
\text { Managerial Guiding } \\
\text { Principles }\end{array}$ & $\begin{array}{l}\text { Vision } \\
\text { KM Governance Principles (strategic alignment, articulation between } \\
\text { quality and organizational learning management) } \\
\text { Main Development Axes } \\
\text { Indicators }\end{array}$ \\
\hline & $\begin{array}{l}\text { (4) } \\
\text { ad hoc Infrastruc- } \\
\text { tures }\end{array}$ & $\begin{array}{l}\text { Content and Document Management Systems } \\
\text { Collaborative Information Systems } \\
\text { Organizational conditions encouraging interaction, communication, } \\
\text { and knowledge sharing }\end{array}$ \\
\hline \multirow{3}{*}{$\begin{array}{c}\mathrm{O} \\
\mathrm{P} \\
\mathrm{E} \\
\mathrm{R} \\
\mathrm{A} \\
\mathrm{T} \\
\mathrm{I} \\
\mathrm{N} \\
\mathrm{G}\end{array}$} & $\begin{array}{l}\text { (5) } \\
\text { Generic KM Proc- } \\
\text { esses }\end{array}$ & $\begin{array}{l}\text { Locating Process } \\
\text { Preserving Process } \\
\text { Enhancing Process } \\
\text { Actualizing Process }\end{array}$ \\
\hline & $\begin{array}{l}6 \\
\text { Organizational } \\
\text { Learning Process }\end{array}$ & $\begin{array}{l}\text { Team Learning Processes } \\
\text { New Organizational Structures Experiments } \\
\text { General Vision, and Systemic Approach } \\
\text { Routines (defensive or constructive) } \\
\text { Knowledge Dissemination } \\
\text { Constant Evolution versus Change [13] }\end{array}$ \\
\hline & $\begin{array}{l}7 \\
\text { Methods and } \\
\text { Supporting Tools }\end{array}$ & $\begin{array}{l}\text { General Methods and Tools } \\
\text { Knowledge Engineering, Artificial Intelligence (Semantic WEB and } \\
\text { Ontology) } \\
\text { CSCW -Computer Supported Cooperative Work (Multi-agents Sys- } \\
\text { tems) } \\
\text { Social Networks (Identification, Visualization, and Informal Social } \\
\text { Network Analysis Systems) } \\
\text { Impact of Web 2.0 }\end{array}$ \\
\hline
\end{tabular}

\section{Assessing the Enterprise's KM Maturity Level}

The Enterprise's KMS components materialize partial or total MGKME's elements. Thus, in a specific context, we can identify and analyze the Knowledge Management System Components implemented in the real field, and assess the maturity level by comparing these components with the MGKME elements.

Accordingly, when referring to MGKME, it is possible to measure the status of the Enterprise's KMS. This status combined with the characteristics of the IT Governance Maturity Model [3], enable to assess the Enterprise's KM Maturity level. You will find the characteristics of each level of maturity in Table 3. 
Table 3. The Enterprise's KM Maturity levels

\begin{tabular}{|c|c|}
\hline $\begin{array}{l}\text { Maturity } \\
\text { levels }\end{array}$ & Characteristics \\
\hline $\begin{array}{c}\text { Level } 0 \\
\text { Non-existent }\end{array}$ & $\begin{array}{l}\text { There is a total absence of recognizable Knowledge Management System. The } \\
\text { company did not become aware that Knowledge Management must be studied and be } \\
\text { considered. }\end{array}$ \\
\hline $\begin{array}{c}\text { Level } 1 \\
\text { Initial/Ad hoc }\end{array}$ & $\begin{array}{l}\text { The company became aware of the importance of Knowledge Management. How- } \\
\text { ever, she has no global vision. } \\
\text { There are no standardized processes but approaches in this sense tend to be applied } \\
\text { on an individual basis. } \\
\text { The implementation of Knowledge Management System or one of its components is } \\
\text { not organized. }\end{array}$ \\
\hline $\begin{array}{l}\text { Level } 2 \\
\text { Repeatable but } \\
\text { intuitive }\end{array}$ & $\begin{array}{l}\text { Knowledge Management System is badly identified and is characterized by a partial } \\
\text { implementation of the MGKME's elements. } \\
\text { The processes are developed until the stage where different persons executing the } \\
\text { same task use similar procedures. } \\
\text { There is no formal training or no communication of standard procedures, and respon- } \\
\text { sibility is left with the individual. One rests a lot on individual knowledge increasing } \\
\text { so the probability to make errors. }\end{array}$ \\
\hline $\begin{array}{c}\text { Level } 3 \\
\text { Defined Process }\end{array}$ & $\begin{array}{l}\text { Knowledge Management System is well identified and is characterized by a partial } \\
\text { implementation of the MGKME's elements. } \\
\text { Procedures were standardized, informed and communicated by way of sessions of } \\
\text { training. However, their use is left with the initiative of each, and it is likely that } \\
\text { abnormalities will be noticed. } \\
\text { Procedures are not sophisticated but formalize existing practices. }\end{array}$ \\
\hline $\begin{array}{l}\text { Level } 4 \\
\text { Managed and } \\
\text { Measurable }\end{array}$ & $\begin{array}{l}\text { Knowledge Management System is well identified and is characterized by a partial } \\
\text { implementation of the MGKME's elements. } \\
\text { It is possible to control and to measure correspondence to procedures, and to act } \\
\text { when processes seem not to work correctly. } \\
\text { Processes are in constant improvement and correspond to a good practice. } \\
\text { The automation and the use of tools are made in a limited or partial way. }\end{array}$ \\
\hline $\begin{array}{c}\text { Level } 5 \\
\text { Optimized }\end{array}$ & $\begin{array}{l}\text { Knowledge Management System is well identified and is characterized by a total } \\
\text { implementation of the MGKME's elements. } \\
\text { Processes reached the level of the best practices, further to a constant improvement } \\
\text { and to a comparison with the other companies. }\end{array}$ \\
\hline
\end{tabular}

\section{Future Trends}

In the Knowledge Society, Enterprises are concerned with Knowledge Management $(\mathrm{KM})$ as a key factor for improving their efficiency and competitiveness. In this article, we propose an Enterprise's KM maturity level analysis transposed from the IT Governance Maturity Model suggested in COBIT $^{\circledR}$, which rests on the MGKME, a Model for General Knowledge Management within the Enterprise. We expect that the MGKME will serve as an open model that allows everyone to take into account his own situation, to establish his own KM Empirical Model, to supply a KM vision to his company, and to be able to assess where the company's KMS is and where it has to go. Moreover, the MGKME can serves as a template for the design and the implementation of a KMS including individuals as users who are also components of the system. 
In the future, we should complete the MGKME, by extending our study and developing appropriated methods, completing our set of qualitative indicators and specific tools to enable assessing the status of an Enterprise's KMS.

\section{References}

1. CEN-CWA 14924-1 : Knowledge Management Framework. In: European Guide to Good Practice in Knowledge Management (Part 1). Brussels: CEN, CWA 14924-1:2004 (E) (2004) (June 19, 2004), ftp: / / cenftp1. cenorm. be/PUBLIC/CWAs / e-Europe/ KM/CWA14924-01-2004-Mar.pdf

2. Wiig, K.: People-Focused Knowledge Management. How Effective Decision Making Leads to Corporate Success. Elsevier Butterworth-Heinemann, Burlington (2004)

3. COBIT $^{\circledR}$ : Control Objectives for Information and Related Technology. Control Objectives, Management Guidelines, Maturity Models, 4th edn. IT Governance Institute, Rolling Meadows Illinois (2005)

4. Coakes, E.: Knowledge Management: A Sociotechnical Perspective. In: Cokes, E., Willis, D., Clarke, S. (eds.) Knowledge Management in the Sociotechnical World ch. 2, pp. 4-14. Springer, London (2002)

5. Porter, M.E.: Competitive Advantage: Creating and Substaining Superior Performance. The Free Press, New York (1985)

6. Deming, W.E.: Out of the Crisis. MIT Press International, Cambridge (1982)

7. Argyris, C., Schön, D.A.: Organizational Learning II. Theory, Method, and Practice. Addison-Wesley Publishing Company, Readings (1996)

8. Grundstein, M.: Knowledge Workers as an Integral Component in Global Information System Design. In: Law, W. (ed.) Information Resources Management: Global Challenges ch. XI, pp. 236-261. Idea Group Inc., Hershey (2007)

9. Nonaka, I., Takeuchi, H.: The Knowledge Creating Company. Oxford University Press, New York (1995)

10. Nonaka, I., Konno, N.: The Concept of Ba: Building a Foundation for Knowledge Creation. California Management Review 40(3), 40-54 (Spring 1998)

11. Nonaka, I., Toyama, R., Konno, N.: SECI, Ba and Leadership: A Unified Model of Dynamic Knowledge Creation. Long Range Planning 33, 5-34 (2000)

12. Rosenthal-Sabroux, C., Grundstein, M.: A Global Vision of Information Management. In: Workshop MoDISE-EUS 2008 Model Driven Engineering: Enterprise, User ad System Models, CAISE 2008, Montpellier, France (2008)

13. Alter, N.: L'innovation ordinaire. Presses Universitaires de France, Paris (2000) 